International Business and Global Economy 2019, no. 38, pp. 24-37

Biznes międzynarodowy w gospodarce globalnej 2019, nr 38, s. 24-37

Edited by the Institute of International Business, University of Gdańsk

ISSN 2300-6102

e-ISSN 2353-9496

DOI 10.4467/23539496IB.19.002.11501

Małgorzata Czermińska

Krakowska Akademia im. A.F. Modrzewskiego

Joanna Garlińska-Bielawska

Uniwersytet Ekonomiczny w Krakowie

Marta Ulbrych

Uniwersytet Ekonomiczny w Krakowie

\title{
Funkcjonowanie unii celnej między Unią Europejską a Turcją - stan i perspektywy
}

Celem artykułu jest prezentacja wyników badania dotyczącego funkcjonowania unii celnej pomiędzy Unią Europejską a Turcją. W opracowaniu wykorzystano metodę krytycznej analizy literatury przedmiotu oraz przegląd dokumentów źródłowych i danych statystycznych, co pozwoliło zidentyfikować słabości oraz wskazać przesłanki modernizacji i proponowane kierunki zmian obowiązującego porozumienia. Za podstawowy mankament umowy należy uznać fakt, że obejmuje ona jedynie liberalizację handlu artykułami przemysłowymi. Ponadto Turcja nie ma statusu obserwatora w unijnym Komitecie ds. Polityki Handlowej. Z tych powodów w grudniu 2016 r. Komisja Europejska zaproponowała rewizję obowiązującej umowy celnej z Turcją i poszerzenie relacji handlowych poprzez stworzenie nowego rodzaju umowy handlowej. Proponuje się, by do ram regulacyjnych nowej umowy włączyć dodatkowe obszary, $w$ tym przede wszystkim rolnictwo, usługi oraz dostęp do przetargów publicznych.

Słowa kluczowe: unia celna, Unia Europejska, Turcja

Klasyfikacja JEL: F15, F4

\section{The functioning of the customs union between the European Union and Turkey - state and prospects}

The aim of the paper is to present the results of a research into the functioning of the customs union between the European Union and Turkey. The survey uses a method of critical analysis of the literature and a review of source documents and statistical data, which allowed to identify the weaknesses and indicate the reasons for modernization and proposed directions of changes of the current agreement. The main drawback of the agreement is that it only covers the liberalization of trade in industrial goods. In addition, Turkey does not have observer status in the EU Trade Policy Committee. For these reasons in December 2016 the European Commission proposed a review of the existing customs union agreement with Turkey and an extension of trade relations by creating a new type of trade agreement. It is proposed to include additional areas in the regulatory framework of the new agreement, in particular agriculture, services, and access to public tenders.

Keywords: customs union, European Union, Turkey

JEL classification: F15, F4 


\section{Wprowadzenie}

Po II wojnie światowej Turcja jako jedyne państwo muzułmańskie rozpoczęła ścisłą współpracę z państwami Europy Zachodniej. Konsekwencją tego procesu było podpisanie Układu ustanawiającego stowarzyszenie między Europejską Wspólnotą Gospodarczą (EWG) a Turcją w 1963 r., który zawierał deklarację o potrzebie wzmocnienia kontaktów gospodarczych i utworzeniu unii celnej, co ostatecznie osiągnięto $\mathrm{w} 1995 \mathrm{r}$. Wynegocjowane wówczas porozumienie satysfakcjonowało obydwie strony - dla EWG istotne znaczenie miało przede wszystkim geostrategiczne położenie partnera, po stronie tureckiej dominowały natomiast przesłanki natury gospodarczej, w tym uzyskanie dostępu do rynku zbytu, możliwość otrzymania wsparcia finansowego czy obniżenie ceł na import tureckich towarów [Kalicka-Mikołajczyk, Daulenov, 2011, s. 103]. Usunięcie barier celnych oraz harmonizacja norm przyniosły korzyści obydwu stronom. Od wejścia w życie unii celnej wartość handlu dwustronnego zwiększyła się ponad czterokrotnie do poziomu 153,4 mld EUR rocznie. Turcja ma istotne znaczenie handlowe dla rynku wewnętrznego - z udziałem 3,9\% była piątym największym partnerem handlowym Unii Europejskiej (UE) w 2018 r. [EC, 2019b]. UE jest dominującym rynkiem eksportowym dla Turcji (aż 50\% wartości tureckiego eksportu trafia do krajów członkowskich UE), co zapewne stymuluje wzrost produktywności [Kwaśny, Mroczek, Ulbrych, 2017, s. 352]. Problematyka wpływu unii celnej na gospodarki państw objętych porozumieniem była przedmiotem licznych analiz, w których wskazywano na jej pozytywny, acz daleki od oczekiwanego wpływ na gospodarkę turecką [Dawar, Harwell, Togan, 2018; Keskin, 2009]. Zarówno w dyskursie naukowym, jak i politycznym pojawia się coraz więcej głosów wskazujących na konieczność uaktualnienia obowiązującej umowy ze względu na nieprzystosowanie jej zakresu i zasad do aktualnych uwarunkowań międzynarodowej wymiany handlowej [ENC, 2017]. Co więcej, wynegocjowane w 1995 r. porozumienie od początku traktowano jako konstrukcję tymczasową, stanowiącą etap na drodze do pełnego członkostwa Turcji w UE.

Celem opracowania jest prezentacja wyników analizy funkcjonowania unii celnej pomiędzy Unią Europejską a Turcją z uwzględnieniem przesłanek jej modernizacji oraz wskazanie proponowanych kierunków zmian w zakresie obowiązującego porozumienia. W badaniu wykorzystano metodę krytycznej analizy literatury przedmiotu oraz analizę dokumentów źródłowych i danych statystycznych. 


\section{Geneza i istota stosunków Turcji z Unią Europejską}

Debata na temat przynależności Turcji do Europy od dekad budzi wiele kontrowersji. Problematyczne jest nie tylko położenie geograficzne kraju (jedynie 3\% dzisiejszej powierzchni Turcji znajduje się na kontynencie europejskim), ale przede wszystkim wymiar tożsamościowy wzajemnych relacji. W tym kontekście warto przeanalizować historyczne związki Republiki Turcji z Europą, których początków należy szukać $\mathrm{w}$ ruchu reformatorskim zwanym tanzimatem, czyli reorganizacją. Koncepcja ta została opracowana w połowie XIX w. i stanowiła przyczynek do budowy nowoczesnej Republiki proklamowanej w 1923 r. Społeczną i polityczną modernizację kraju w oparciu o rozwiązania zachodnioeuropejskie kontynuowano następnie $\mathrm{w}$ ramach polityki kemalizmu w latach 20. i 30. XX w. [Ulbrych, 2013, s. 78]. U podstaw kemalizmu leżało przesłanie pierwszego prezydenta Republiki, Mustafy Kemala Paşy, o potrzebie budowy nowoczesnego świeckiego państwa ściśle związanego z Europą i opartego na sześciu zasadach ustrojowych, tzw. sześciu strzałach kemalizmu: republikanizmie, nacjonalizmie, populizmie, etatyzmie, laicyzmie i rewolucjonizmie [Chmielowska, Sobczak, 2016, s. 213]. Równocześnie wdrażana koncepcja polityki wewnętrznej determinowała założenia strategii zagranicznej państwa, zakładając, że reorganizacja kraju stanowi instrument wzmocnienia jego pozycji zewnętrznej poprzez zjednanie sobie mocarstw europejskich przeciwko Rosji - z perspektywy Turcji głównego zagrożenia dla bezpieczeństwa kraju [Wódka, 2012, s. 81-82]. W wyniku tych zmian Turcja zaczęła być postrzegana jako wiarygodny partner przez ówczesnych przywódców europejskich, czego formalnym potwierdzeniem było przyjęcie kraju do Rady Europy w sierpniu 1949 r.

Lata 80. XX w. i dojście do władzy Partii Ojczyźnianej (Anavatan Partisi ANAP) z Turgutem Özalem na czele przyniosły kolejny, ważny etap kształtowania pozycji Turcji na arenie międzynarodowej. Polityka tego okresu opierała się na czterech komponentach - podkreślaniu nowych możliwości w konsekwencji rozpadu ZSRR oraz roli i znaczenia Turcji $\mathrm{w}$ świecie zachodnim, $\mathrm{w}$ świecie muzułmańskim, a także jako pomostu między Wschodem a Zachodem [Gozen, 1996, s. 70]. Mimo że w tym czasie można zaobserwować wzrost aktywności tureckiej na Bliskim Wschodzie, bardzo ważnym elementem ówczesnej polityki zagranicznej były aspiracje Turcji do członkostwa we Wspólnocie Europejskiej (WE), czego wyrazem było złożenie wniosku o akcesję w $1987 \mathrm{r}$. W odpowiedzi na wniosek w 1999 r. UE oficjalnie uznała Turcję za kandydata, ale negocjacje rozpoczęły się dopiero w 2005 r. w oparciu o specjalne i szczegółowe ramy. Turcja nie otrzymała gwarancji przyjęcia do UE, ponieważ jej kandydatura od początku budzi wśród państw członkowskich liczne kontrowersje o charakterze politycznym, kulturowym i gospodarczym. Już w 2006 r. negocjacje zostały częściowo zawieszone 
ze względu na sprzeciw Turcji wobec poszerzenia unii celnej i otwarcia tureckich portów oraz lotnisk dla cypryjskich statków i samolotów [zob. Szymański, 2011]. Postępy w rozmowach negocjacyjnych są powolne - dotychczas otwarto 16 spośród 35 rozdziałów negocjacyjnych. Ponadto po represjach wprowadzonych przez rząd turecki w wyniku nieudanego zamachu stanu w lipcu 2016 r. negocjacje zostały zamrożone [PE, 2017]. Perspektywa przystąpienia Turcji do Unii staje się zatem coraz bardziej odległa - w 2018 r. Rada stwierdziła jednomyślnie, że negocjacje akcesyjne z Turcją utknęły w martwym punkcie i nie można rozważać otwarcia ani zamknięcia żadnych kolejnych rozdziałów negocjacyjnych [EC, 2019a].

Brak pozytywnych sygnałów ze strony UE oraz ideologia rządzącej w Turcji Partii Sprawiedliwości i Rozwoju (Adalet ve Kalkınma Partisi - AKP) spowodowały zmianę priorytetów polityki zagranicznej Turcji w ostatnich dwóch dekadach. Jednym z najważniejszych założeń programowych jest zmiana polityki na proaktywną i wielowymiarową. Motywacja ekonomiczna polityki zagranicznej AKP jest niezaprzeczalna - rząd w Ankarze, kontynuując zainicjowany w latach 80. XX w. kierunek stymulacji eksportu jako motoru wzrostu gospodarczego, dąży do zacieśnienia stosunków handlowych z państwami sąsiednich regionów [Migdalovitz, 2010, s. 43]. Zasadniczą przesłanką nowego modelu jest realizacja koncepcji tzw. strategicznej głębi Ahmeta Davutoğlu, która opiera się na dwóch wymiarach: głębi geograficznej oraz głębi historycznej. Pierwszy z nich podkreśla, że Turcja, będąca spadkobiercą Imperium Osmańskiego, jest usytuowana w centrum wielu geopolitycznych płaszczyzn oddziaływania, jest „krajem centralnym", który nie może ograniczać się jedynie do odgrywania roli pomostu łączącego Wschód i Zachód. Wymiar głębi historycznej także odnosi się do osmańskiej przeszłości kraju i faktu, że znajdował się on w epicentrum wielu wydarzeń historycznych [Aslan, Eralmac, Ozaydin, 2016, s. 6-7]. Wyjątkowe położenie Turcji pomiędzy newralgicznymi obszarami świata powoduje, że prowadzona przez nią polityka powinna być wielosektorowa, a jej stosunki z otoczeniem międzynarodowym dopełniać współpracę regionalną. Odejście premiera Davutoğlu w 2016 r. i postępujący kryzys wewnętrzny okazały się jednak punktem zwrotnym w formułowaniu priorytetów polityki zagranicznej Turcji. W ostatnich latach można zaobserwować malejące znaczenie promocji kraju jako "potęgi” regionalnej na korzyść bardziej nieplanowanej polityki opartej na celowości [Dalacoura, 2017, s. 2].

\section{Unia celna między Unią Europejską a Turcją}

Dążenia Turcji do uzyskania członkostwa w EWG zostały zainicjowane na długo przed złożeniem wniosku o akcesję w 1987 r. Już 31 lipca 1959 r. Turcja złożyła wniosek o stowarzyszenie z EWG. 12 września 1963 r., po czterech latach 
negocjacji, zawarto układ o stowarzyszeniu między EWG a Turcją (układ z Ankary), na mocy którego strony zgodzily się na utworzenie unii celnej [WE, 1963]. 23 listopada 1970 r. podpisano protokół dodatkowy, w którym określono harmonogram zniesienia ceł i kontyngentów na towary przemysłowe w handlu wzajemnym oraz wprowadzenia swobodnego przepływu pracowników (w ciągu 22 lat). Protokół ten stanowi integralną część układu z Ankary, który wszedł w życie w styczniu 1973 r. Ostatni etap wdrażania unii celnej między Turcją a Unią Europejską rozpoczął się 31 grudnia 1995 r. na podstawie Decyzji Rady Stowarzyszeniowej nr 1/95 z dnia 22 grudnia 1995 r. [UE, 1995], 32 lata po podpisaniu układu z Ankary. Turcja została oficjalnie uznana za kraj kandydujący do UE w grudniu 1999 r., a negocjacje akcesyjne rozpoczęły się 3 października 2005 r.

Zasadniczo decyzja 1/95 opiera się na dwóch głównych filarach: zniesieniu różnego rodzaju barier technicznych, administracyjnych, prawnych i finansowych w handlu wzajemnym oraz stworzeniu uczciwej konkurencji w handlu towarami znajdującymi się w obrocie. Decyzja przewidywała dwa sposoby osiągnięcia tych celów. Po pierwsze, ustanowiła swobodny przepływ towarów przemysłowych na wspólnym obszarze celnym. Po drugie, zobowiązywała Turcję do dostosowania się do wspólnotowego dorobku prawnego (acquis communautaire) w kilku obszarach rynku wewnętrznego. Na mocy tej regulacji cła na towary przemysłowe w obrocie między Turcją i UE zostały zniesione. Zaznaczyć należy, że dotyczyło to Turcji, gdyż praktycznie wszystkie produkty przemysłowe pochodzenia tureckiego miały zapewniony bezcłowy dostęp do rynku Wspólnoty od 1973 r. w wyniku postanowień układu stowarzyszeniowego z $1963 \mathrm{r}$. oraz protokołu dodatkowego z $1970 \mathrm{r}$. Wraz z ustanowieniem unii celnej wszystkie cła i opłaty o skutku równoważnym zostały zniesione [UE, 1995, art. 4], wszystkie ograniczenia ilościowe między stronami zostały zakazane [UE, 1995, art. 5-6], a Turcja przyjęła wspólną taryfę celną w imporcie [UE, 1995, art. 13].

Towary przemysłowe, na które zniesiono cła zgodnie z art. 3 decyzji 1/95, to:

- towary wyprodukowane we Wspólnocie lub Turcji, w tym całkowicie lub częściowo uzyskane lub wyprodukowane z produktów pochodzących z państw trzecich, które znajdują się w swobodnym obrocie we Wspólnocie lub w Turcji,

- towary pochodzące z państw trzecich i dopuszczone do swobodnego obrotu we Wspólnocie lub w Turcji (zgodnie z art. 3 ust. 2 decyzji 1/95, towary z państw trzecich znajdują się w swobodnym obrocie, gdy formalności przywozowe są spełnione, wszelkie należne cła lub opłaty o skutku równoważnym zostały nałożone przez każdą ze stron i jeżeli produkty nie skorzystały z żadnego zwrotu tych ceł lub opłat ${ }^{1}$ ).

1 Potwierdzenie spełnienia tych trzech warunków w przypadku towarów przemysłowych stanowi certyfikat ATR. Zasadniczo świadectwo ATR stanowi dowód, że towary znajdują się w swobodnym obrocie, i wskazuje ich pochodzenie. Jest on wykorzystywany przez organy celne do ustalenia specjalnej stawki celnej ( $w$ tym przypadku wynosi ona zero), a bez niego obowiązują normalne opłaty celne. 
W protokole dodatkowym zawarto klauzulę standstill, zgodnie z którą ani UE, ani Turcja nie mogą wprowadzić żadnych ograniczeń ponad te, które istniały w momencie wejścia w życie protokołu dodatkowego. Decyzja 1/95 odnosiła się wyłącznie do swobodnego przepływu towarów, a zatem inne wolności wspólnego rynku (dotyczące na przykład usług i zamówień publicznych) pozostają poza zakresem unii celnej. Są one przedmiotem dalszych decyzji Rady Stowarzyszenia.

Zapisy protokołu nakładają na Turcję obowiązek dostosowania się do wspólnej polityki handlowej UE w odniesieniu do krajów niebędących członkami UE. W szczególności dotyczy to zobowiązania do stopniowego dostosowania się do preferencji celnych UE. $Z$ tego też względu przyjęto nowe prawo celne podobne do kodeksu celnego WE, a ponadto wprowadzono Nomenklaturę Scaloną, przepisy dotyczące klasyfikacji taryfowej, zwolnienia z ceł, zawieszenia ceł i niektórych kontyngentów taryfowych ${ }^{2}$. Wprowadzono również powiązania z odpowiednimi komputerowymi systemami celnymi UE.

Ponadto Turcja nie powinna stosować ceł przywozowych niższych niż określone we wspólnej taryfie celnej dla jakiegokolwiek towaru. Postanowienie to doprowadziło to do stopniowej redukcji ceł tureckich na większość towarów przemysłowych i do selektywnej liberalizacji ceł na towary rolne z krajów trzecich, z którymi UE zawarła umowy o wolnym handlu. Towary z krajów, z którymi UE zawarła umowy o wolnym handlu, a Turcja nie, mogą zostać wprowadzone do Turcji bezcłowo, jeśli zostały przeładowane w UE, lecz w przypadku przywozu bezpośrednio do portów tureckich naliczane są opłaty przywozowe ${ }^{3}$. Powoduje to zakłócenia w handlu, stawiając firmy tureckie w niekorzystnej pozycji konkurencyjnej względem eksporterów unijnych. Niemniej jednak przed powstaniem unii celnej udziały te były jeszcze wyższe, ponieważ ponad połowa tureckiego importu przypadała na UE i podlegała ocleniu4.

Zmiany spowodowały, że nominalna stopa protekcji (NSP) w imporcie Turcji znacznie się zmniejszyła ${ }^{5}$. Przed utworzeniem unii celnej NSP Turcji w handlu z UE wynosiła 10,2\%, a w handlu z krajami trzecimi 22,1\%. Wraz z utworzeniem

Co ciekawe, świadectwo to podaje jedynie status pochodzenia i nie jest świadectwem pochodzenia jako takim. Funkcję świadectwa pochodzenia pełni certyfikat EUR1, który jest wykorzystywany do importu większości produktów rolnych lub wyrobów żelaznych i stalowych. Więcej w: [HMRC, 2018].

2 Więcej na temat kodeksu celnego, taryfy celnej i nomenklatury celnej w: [Czermińska, 2016, s. 44-49].

3 Turcja zawarła 22 umowy o preferencyjnym handlu (nie licząc unii celnej z UE) m.in. z krajami Bałkanów Zachodnich, krajami basenu Morza Śródziemnego, Mauritiusem, Malezją, Koreą Południową, Chile, Gruzją i Ukrainą; więcej w: [WTO, 2019]. Turcja nie zawarła zatem umów preferencyjnych z krajami Afryki (w tym z Republiką Południowej Afryki), Karaibów i Pacyfiku oraz z Meksykiem, z którymi to państwami Unię Europejską łączą preferencyjne umowy handlowe.

4 Od wejścia w życie unii celnej średnia stawka celna w taryfie tureckiej dla towarów przemysłowych spadła znacząco, średnio o około 4,8\%. Przychody z tytułu należności celnych w Turcji wzrosły jednak w ostatnich latach w wyniku wyższego importu [WB, 2014, s. 20].

5 Nominalna stopa protekcji wyraża się relacją cła na dany towar do jego ceny światowej. 
unii celnej NSP w 2001 r. w wymianie handlowej z UE wyniosła 1,3\%, a w 2003 r. $\mathrm{w}$ handlu z krajami trzecimi 6,9\% [EP, 2016]. Turcja nie uczestniczy również w tworzeniu wspólnej taryfy zewnętrznej UE ani wspólnej polityki handlowej wobec państw i terytoriów trzecich. Decyzje w tych obszarach są podejmowane przez UE przy niewielkim uwzględnieniu strategicznych interesów Turcji lub bez ich uwzględnienia. Turcja stosuje zatem unijne stawki celne dla większości towarów przemysłowych, a także komponentów przemysłowych przetworzonych produktów rolnych, jest jednak wyłączona z podejmowania decyzji w tym zakresié.

Turcja zobowiązała się również do eliminacji barier technicznych w handlu (technical barriers to trade - TBT). Istnieją zasadniczo dwa sposoby eliminacji barier technicznych: harmonizacja i wzajemne uznawanie (zasada prawa UE, zgodnie z którą produkt legalnie sprzedawany w jednym państwie członkowskim może być sprzedawany w innym państwie członkowskim). Od czasu ustanowienia unii celnej Turcja dostosowała swoje standardy do norm europejskich i międzynarodowych. Ponadto zharmonizowała swoje ustawodawstwo techniczne z prawodawstwem UE, szczególnie w obszarze dyrektyw nowego i globalnego podejścia7. Harmonizacja przepisów w obszarze starego podejścia jest jednak nadal niepełna. Wprawdzie Turcja przyjęła przepisy dotyczące nawozów, środków farmaceutycznych, pojazdów silnikowych i kosmetyków, niektóre regulacje dotyczące kosmetyków nie są jednak zgodne z przepisami UE i sektorowymi przepisami technicznymi dotyczącymi farmaceutyków i wymagają dalszego dostosowania. Ponadto przepisy tureckie nie zezwalają na wzajemne uznawanie produktów farmaceutycznych. Nie ma wzajemnego uznawania certyfikatów „dobrej praktyki wytwarzania" w odniesieniu do rejestracji sprzedawanych na rynkach produktów farmaceutycznych [WB, 2014, s. 36].

Turcja była zobowiązana dostosować się do i wdrożyć przepisy UE dotyczące wspólnej polityki handlowej, instrumentów ochrony rynku, w tym procedur antydumpingowych, ceł wyrównawczych, środków nadzoru i środków ochronnych, a także zarządzania kontyngentami ilościowymi [EP, 2016] . Ilekroć Unia wprowadza środki ochronne, wyrównawcze lub antydumpingowe, na Turcji zasadniczo spoczywa obowiązek dostosowania się do nich i przyjęcia identycznych środków w handlu z państwami trzecimi. Środki o charakterze defensywnym

6 Turcja nie ma nawet statusu obserwatora w unijnym Komitecie ds. Polityki Handlowej. To wykluczanie z procesu podejmowania decyzji mogło się zresztą zakończyć zawieszeniem unii celnej przez Turcję po tym, jak UE chciała wyłączyć ten kraj z udziału w negocjacjach Transatlantyckiego Partnerstwa w dziedzinie Handlu i Inwestycji (Transatlantic Trade and Investment Partnership-TTIP).

7 Więcej na ten temat w: [Czermińska, 2010, s. 28-35].

8 Instrumenty ochrony rynku (stosowane $\mathrm{w}$ imporcie) można podzielić na instrumenty stałej protekcji (np. cła, taryfa celna) i instrumenty protekcji uwarunkowanej, czyli czasowej (temporary trade barriers - TTBs) [Bown, 2011, s. 2]. Można wyróżnić trzy zasadnicze grupy środków TTBs: antydumpingowe (antydumping - AD), wyrównawcze (countervailing - AS) i środki ochrony przed nadmiernym importem (safeguard - SG). 
(trade defence instruments - TDI) mogą być również stosowane między Unią Europejską i Turcją, należy jednak podkreślić, że w tym przypadku stosowanie takich instrumentów jest sprzeczne z zasadami jednolitego rynku i unii celnej.

Turcja musiała wreszcie także przyjąć unijny dorobek prawny dotyczący polityki konkurencji i prawa własności intelektualnej, jest zatem zobowiązana dostosować się do regulacji europejskich w obszarach wykraczających poza dostosowanie ceł i zniesienie ograniczeń ilościowych, a mianowicie w zakresie barier technicznych $\mathrm{w}$ handlu, praw własności intelektualnej i przemysłowej oraz konkurencji. Zobowiązania Turcji wykraczają więc poza wymogi niezbędne do zapew- nienia swobodnego przepływu towarów i utworzenia unii celnej sensu stricto. Jednocześnie unia ta nie obejmuje usług, prawa przedsiębiorczości, zamówień publicznych i rolnictwa (z wyjątkiem niektórych przetworzonych produktów rolnych) [Fakura, 2018, s. 3].

Turcja przyjęła ponadto obowiązek zharmonizowania swoich stosunków handlowych z krajami trzecimi na wzór unijnych. Turcja zasadniczo zawiera preferencyjne umowy handlowe z tymi samymi państwami trzecimi co UE, a zatem równolegle do umów, z którymi Unia takie umowy już zawarła. W negocjacjach umów handlowych UE Turcja jednak nie uczestniczy, gdyż nie jest państwem członkowskim. Ponieważ strony umów o wolnym handlu negocjują umowy na zasadzie wzajemnych korzyści, niechętne zachowanie niektórych państw trzecich podczas negocjacji powoduje znaczne opóźnienie Turcji w dotrzymaniu terminów zawarcia analogicznych umów handlowych skutkujące nieprawidłowościami w funkcjonowaniu unii celnej. Koszt alternatywny niekompletnych umów znajduje odzwierciedlenie w ograniczonych korzyściach z mniejszego dostępu do globalnego rynku usług i towarów. Typowymi przykładami są kraje śródziemnomorskie (Algieria, Egipt, Liban), Republika Południowej Afryki i Meksyk. Państwa takie jak Algieria, Meksyk czy Republika Południowej Afryki, które zawarły umowy handlowe z UE, nie mają takiej samej motywacji do negocjowania umów o wolnym handlu z Turcją, ponieważ unia celna zapewnia im bezcłowy dostęp do rynku tureckiego przez UE. Ta asymetryczna relacja naraża tureckich producentów na konkurencję zewnętrzną bez możliwości konkurowania na zasadzie wzajemności na rynkach krajów trzecich. W odwecie Turcja wdrożyła kontrolę pochodzenia importu z UE, szczególnie w sektorach wrażliwych, aby ustalić, czy pochodzą one z krajów, które mają umowę o wolnym handlu z UE. Przykładem jest wprowadzenie przez Turcję środków ochronnych przeciwko meksykańskim samochodom [Nas, Özer, 2017, s. 42]. 


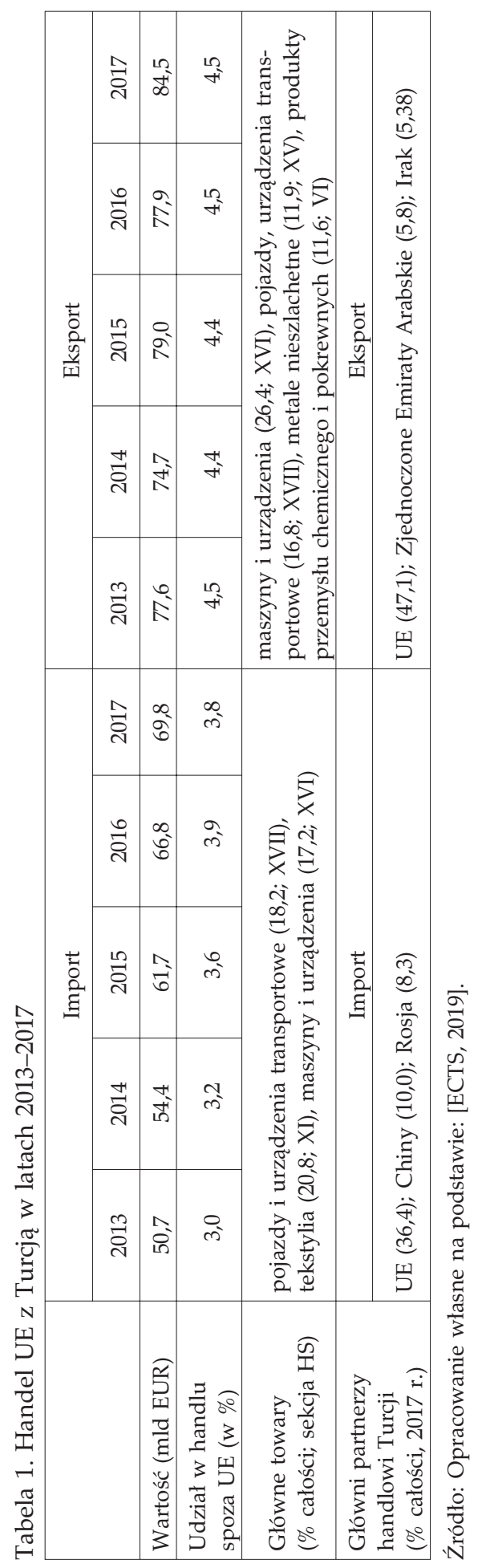


Turcja jest trzecim, obok Andory i San Marino, państwem, które tworzy unię celną z Unią Europejską, nie będąc jej członkiem. Ze względu niewielki potencjał gospodarczy znaczenie unii celnych Andory i San Marino, o populacjach odpowiednio 84 tys. i 31 tys., jest jednak niewielkie. Turcja, mająca populację liczącą 72 milionów i będąca szesnastą co do wielkości gospodarką na świecie, a także szóstą co do wielkości gospodarką w Europie, jest znaczącym partnerem handlowym UE [Eurostat, 2019]. Ponadto Turcja przyjęła większy zakres acquis w obszarze wspólnego rynku.

Ważną pozycję w imporcie z Turcji zajmują tekstylia. Handel z Turcją stanowi ok. $4 \%$ handlu zewnętrznego UE, dla Turcji natomiast Unia pozostaje głównym partnerem handlowym.

\section{Modernizacja unii celnej - proponowane kierunki zmian}

W funkcjonowaniu unii celnej Turcja-UE można wskazać następujące problemy [Akman, 2010, s. 17-45]:

- UE ma własne priorytety odzwierciedlone w zawartych umowach o wolnym handlu, które nie uwzględniają interesów Turcji,

- Turcja ponosi straty z tytułu spadku stawek celnych i, co za tym idzie, spadku wpływów z ceł,

- Turcja nie może zawierać umów o wolnym handlu z krajami trzecimi, z którymi UE nie zawarła podobnych porozumień (może ona zawierać umowy o wolnym handlu dopiero po ich zawarciu przez UE), co stawia tureckich eksporterów w niekorzystnej sytuacji w stosunku do eksporterów z UE, którzy mogą uzyskać preferencyjny status, penetrując rynki państw trzecich o kilka lat wcześniej,

- niektórzy partnerzy handlowi UE, którzy zawarli lub negocjują umowy o wolnym handlu z UE, powstrzymują się od zawarcia umów o wolnym handlu z Turcją.

Dodatkowo eksperci Banku Światowego [WB, 2014] zwracają uwagę, że:

- kontyngenty $\mathrm{w}$ transporcie drogowym i zezwolenia tranzytowe utrudniają swobodny przepływ towarów w unii celnej,

- stosowanie instrumentów ochrony handlu, takich jak środki antydumpingowe i ochronne, szkodzi wzajemnej wymianie handlowej,

- istniejący system wizowy ma ograniczający wpływ na stosunki handlowe i biznesowe między UE a Turcją.

Nie ulega wątpliwości, że w drugiej dekadzie XXI w. konieczne są zmiany $\mathrm{w}$ funkcjonowaniu unii celnej UE z Turcją w celu dostosowania jej do istotnych zmian w otoczeniu międzynarodowym i utorowania drogi do wykorzystania 
pełnego potencjału dwustronnego handlu między tymi ważnymi partnerami handlowymi. Mowa przede wszystkim o rozszerzeniu jej zakresu, dalszej harmonizacji i uproszczeniu przepisów i procedur celnych oraz wprowadzeniu mechanizmu rozstrzygania sporów. W grudniu 2016 r. Komisja Europejska zapropo- nowała rozszerzenie zakresu unii celnej o liberalizację handlu towarami rolnymi i usługami oraz nowelizację prawa przedsiębiorczości i zamówień publicznych [EC, 2016]. Taka opcja obejmuje wynegocjowanie zupełnie nowej umowy zgodnej z najnowszymi umowami o wolnym handlu, które UE wynegocjowała z Kanadą czy Koreą Południową - kompleksowej umowy z rozdziałami obejmującymi towary przemysłowe, rolnictwo, usługi, TBT, prawa własności intelektualnej, inwestycje, konkurencję i zamówienia publiczne. Wymagałoby to wprowadzenia znacznych zmian w układzie o stowarzyszeniu, konieczna byłaby zatem nowa decyzja Rady Stowarzyszenia lub nowy protokół do układu. Ponadto Turcja chce mieć wpływ na kształtowanie polityki handlowej UE i pragnie być uwzględniona w jej przyszłych umowach o wolnym handlu. Chce również uprościć procedury dotyczące przemieszczania się tureckich pojazdów ciężarowych przez granice z Bułgarią i Grecją oraz tranzytu między państwami Unii Europejskiej.

\section{Podsumowanie}

Charakter i kierunki polityki zagranicznej Turcji zmieniają się, są jednak tradycyjnie determinowane wielowymiarową tożsamością państwa warunkowaną jej strategicznym położeniem oraz doświadczeniami historycznymi. Jednocześnie Turcja jest państwem najdłużej starającym się o członkostwo w UE oraz jednym z trzech państw, które mają z nią umowę o unii celnej.

Słabością obowiązującego porozumienia jest to, że obejmuje ono jedynie liberalizację handlu artykułami przemysłowymi. Ponadto Turcja nie ma statusu obserwatora w unijnym Komitecie ds. Polityki Handlowej. Z tych powodów Komisja Europejska zaproponowała rewizję obowiązującej umowy celnej z Turcją i poszerzenie relacji handlowych poprzez stworzenie nowego rodzaju umowy handlowej. Proponuje się, by do ram regulacyjnych nowej umowy włączyć dodatkowe obszary, $w$ tym przede wszystkim rolnictwo, usługi oraz dostęp do przetargów publicznych.

Liberalizacja wzajemnego handlu rolnego stanowiłaby duże wyzwanie dla Turcji. Średnia stosowana stawka KNU na towary rolne w Turcji jest wysoka i wynosi 41,8\% (2018 r.), a średnia ważona importem - 18,8\%. Dla porównania w UE jest to odpowiednio $12,8 \%$ oraz $8,1 \%$ [WTO]. Handel rolny podlega również kontyngentom taryfowym i regulacjom cen, które zapewniają wysoki stopień ochrony zarówno dla UE, jak i dla Turcji. Liberalizacja dwustronnego handlu pro- 
duktami rolnymi i przyjęcie wspólnej taryfy zewnętrznej UE dla rolnictwa oznaczałyby znaczny spadek ochrony importu Turcji dla niektórych produktów i zmniejszenie zatrudnienia w gospodarstwach rolnych. Pełna zgodność z regulacjami unijnymi będzie wymagać od Turcji przyjęcia środków wspólnej polityki rolnej (WPR) oraz przyjęcia i stosowania środków sanitarnych i przepisów weterynaryjnych.

W zakresie handlu usługami Turcja i UE mają podobny poziom otwartości, co może ułatwić integrację wymiany usługowej między stronami. Niemniej jednak ważne są różnice sektorowe - UE ma wyższe wskaźniki restrykcyjności niż Turcja dla usług detalicznych i niektórych usług transportowych. Liberalizacja usług będzie wymagać przyjęcia przez Turcję i wdrożenia dla każdego sektora usług, który zamierza zliberalizować, ram regulacyjnych UE.

Podobnie dużym wyzwaniem byłaby dalsza liberalizacja dostępu do zamówień publicznych. Obecnie rynek zamówień publicznych w Turcji nie jest jeszcze otwarty na równych prawach dla wykonawców zagranicznych. Mogą się oni ubiegać wprawdzie o zamówienia publiczne, ale w niektórych przypadkach preferowani są wykonawcy mający siedzibę w Turcji. Ponad to obowiązujące ustawodawstwo tureckie w zakresie zamówień publicznych zostało uznane przez Komisję Europejską za niezgodne z wymogami prawa UE.

\section{Źródła finansowania}

Publikacja została dofinansowana ze środków przyznanych Wydziałowi Prawa, Administracji i Stosunków Międzynarodowych Krakowskiej Akademii im. Andrzeja Frycza Modrzewskiego oraz Wydziałowi Ekonomii i Stosunków Międzynarodowych Uniwersytetu Ekonomicznego w Krakowie w ramach dotacji na utrzymanie potencjału badawczego.

\section{Bibliografia}

Akman S., 2010, The European Union's trade strategy and its reflection on Turkey: An evaluation from the perspective of free trade agreements, paper presented at the IKV Workshop on the Interface between the World Trading System and Global Issues: Challenges for the WTO, Turkey and the European Union, 14-15 May, Istanbul.

Aslan D.H., Eralmac O., Ozaydin S., 2016, Turkey's foreign policy and the Middle East under AKP Rule (2002-2012), Zeszyty Naukowe Uczelni Vistula, no 3.

Bown Ch.P., 2011, Introduction, [w:] The great recession and import protection: The role of temporary trade barriers, ed. Ch.P. Bown, The International Bank for Reconstruction and Development, The World Bank, Washington.

Chmielowska D., Sobczak M., 2016, Demokracja po turecku, Studia Europejskie, nr 4.

Czermińska M., 2010, Swoboda przeptywu towarów jako jedna z wolności wspólnego rynku Unii Europejskiej, Zeszyty Naukowe Uniwersytetu Ekonomicznego w Krakowie, nr 845. 
Czermińska M., 2016, The European Union customs system in the 21st century: Challenges and trends, Trends in the World Economy, no. 8: Global Economy at the Crossroads.

Dalacoura K., 2017, A new phase in Turkish foreign policy: Expediency and AKP survival, Middle East and North Africa Regional Architecture: Mapping Geopolitical Shifts, Regional Order and Domestic Transformation, MENARA.

Dawar K., Harwell Ch., Togan S., 2018, Reforming and renegotiating the EU-Turkey Customs Union, Turkish Policy Quarterly, no. 1.

EC, 2016, Recommendation for a Council Decision authorising the opening of negotiations with Turkey on an Agreement on the extension of the scope of the bilateral preferential trade relationship and on the modernisation of the Customs Union, European Commission, $\operatorname{COM}(2016) 830$ final.

EC, 2019a, Commission Press Release IP/19/2752, Reforms in the Western Balkans and Turkey: Annual assessments and recommendations, European Commission, https://ec.europa.eu/commission/presscorner/detail/en/IP_19_2752 [dostęp: 03.12.2019].

EC, 2019b, European Union: trade in goods with Turkey, European Commission, https://webgate.ec.europa.eu/isdb_results/factsheets/country/details_turkey_en.pdf [dostęp: 20.09.2019].

ECTS, [b.d.], European Commission Trade Statistics, http://ec.europa.eu [dostęp: 05.09.2019].

ENC, 2017, A modernized EU-Turkey customs union: Expert interviews and analysis, European Neighbourhood Council, https://www.tepav.org.tr/upload/files/1491836076-0.A_Modernized_EU_Turkey_Customs_Union.pdf [dostęp: 15.09.2019].

EP, 2016, Bringing EU-Turkey trade and investment relations up to date?, European Parliament, European Parliament's Committee on International Trade, Directorate General for External Relations.

Eurostat, 2019, https://ec.europa.eu/eurostat/statistics-explained/index.php?title=Turkey-EU_-_international_trade_in_goods_statistics [dostęp: 01.09.2019].

Fakura H., 2018, EU-Turkey customs union: Prospects for modernization and lessons for brexit, Chatham House, The Royal Institute of International Affairs, London, https://www. chathamhouse.org/publication/eu-turkey-customs-union-prospects-modernizationand-lessons-brexit [dostęp: 02.09.2019].

Gozen R., 1996, Turgut Özal and Turkish foreign policy: Style and vision, Foreign Policy, no. 3/4. HMRC, 2018, Notice 812: European Union preferences - trade with Turkey, HM Revenue \& Customs, https://www.gov.uk/government/publications/notice-812-european-community-preferences-trade-with-turkey/notice-812-european-community-preferencestrade-with-turkey [dostęp: 1.09.2019].

Kalicka-Mikołajczyk A., Daulenov M., 2011, Unia celna jako forma integracji gospodarczej państw, Acta Universitatis Writislaviensis, no. 3367.

Keskin S., 2009, Impacts of customs union with European Union to the Turkish economy, International Journal of Economics and Finance, no. 2, http://www.sobiad.org/ejournals/journal_IJEF/archieves/ijef2009/05sadettin_keskin.pdf [dostęp: 03.12.2019].

Kwaśny J., Mroczek A., Ulbrych M., 2017, Eksport jako determinanta rozwoju Małopolski, [w:] Handel zagraniczny i biznes międzynarodowy we wspótczesnej gospodarce, red. M. Maciejewski, K. Wach, Uniwersytet Ekonomiczny w Krakowie, Kraków.

Migdalovitz C., 2010, AKP's domestically-driven foreign policy, Turkish Policy Quarterly, no. 4. Misiągiewicz J., 2009, Polityka zagraniczna Turcji po zimnej wojnie, Wydawnictwo Adam Marszałek, Toruń. 
Nas C., Özer Y., 2017, Turkey and EU integration: Achievements and obstacles, Routledge, New York - Oxford.

PE, 2017, Stosunki UE-Turcja. Możliwe scenariusze rozwoju, Parlament Europejski, http://www. europarl.europa.eu/news/pl/headlines/world/20170426STO72401/stosunki-ue-turcjamozliwe-scenariusze-rozwoju [dostęp: 17.09.2019].

Szymański A. (red.), 2011, Turcja i Europa. Wyzwania i szanse, Polski Instytut Spaw Międzynarodowych, Warszawa.

UE, 1995, Decyzja nr 1/95 Rady Stowarzyszenia WE-Turcja z dnia 22 grudnia 1995 r. w sprawie wprowadzenia w życie ostatniego etapu unii celnej, Dziennik Urzędowy Unii Europejskiej, L 13/74, https://eur-lex.europa.eu/legal-content/PL/TXT/PDF/?uri=CELEX: 21996D0213(01)\&from=EN [dostęp: 03.12.2019].

Ulbrych M., 2013, Strategie integracyjne Turcji. Między funkcjonalizacją a regionalizacja, [w:] Terytorializacja lub funkcjonalizacja. Dylematy ugrupowań integracyjnych, red. A. Surdej, J. Brzozowski, Wydawnictwo Adam Marszałek, Torun.

WB, 2014, Evaluation of the EU-Turkey Customs Union, World Bank, report no. 85830-TR, https:// www.worldbank.org/content/dam/Worldbank/document/eca/turkey/tr-eu-customs-union-eng.pdf [dostęp: 03.12.2019].

WE, 1963, Decyzja Rady z dnia 23 grudnia 1963 r. w sprawie zawarcia Układu ustanawiającego stowarzyszenie między Europejską Wspólnotą Gospodarczą a Turcją, Dziennik Urzędowy Wspólnot Europejskich, 217/3685, https://eur-lex.europa.eu/legal-content/PL/TXT/PDF/?uri = CELEX:31964D0732\&from =PL [dostęp: 03.12.2019].

WTO, [b.d.], Tariff profiles, https://www.wto.org/english/res_e/statis_e/tariff_profiles_list _e.htm [dostęp: 05.09.2019].

WTO, 2019, Regional Trade Agreements Database, http://rtais.wto.org [dostęp: 02.09.2019].

Wódka J., 2012, Polityka zagraniczna Turcji. Uwarunkowania wewnętrzne oraz podmioty decyzyjne, Instytut Studiów Politycznych PAN, Wydawnictwo TRIO, Warszawa.

M. Czermińska (ब) emczermi@cyf-kr.edu.pl

Katedra Handlu Zagranicznego, Wydział Prawa, Administracji i Stosunków

Międzynarodowych, Krakowska Akademia im. A.F. Modrzewskiego,

ul. G. Herlinga-Grudzińskiego 1, 30-705 Kraków, Polska

J. Garlińska-Bielawska (『) garlinsj@uek.krakow.pl

Katedra Międzynarodowych Stosunków Gospodarczych, Kolegium Ekonomii, Finansów i Prawa, Uniwersytet Ekonomiczny w Krakowie, ul. Rakowica 27, 31-510 Kraków, Polska

M. Ulbrych (『) ulbrychm@uek.krakow.pl

Katedra Międzynarodowych Stosunków Gospodarczych, Kolegium Ekonomii, Finansów i Prawa, Uniwersytet Ekonomiczny w Krakowie, ul. Rakowica 27, 31-510 Kraków, Polska 